\title{
The Dynamics of the U.S. Trade Balance and the Real Exchange Rate: The J Curve and Trade Costs?*
}

\author{
Preliminary - Please do not circulate without the permission of the authors
}

June 2015

George Alessandria

University of Rochester and NBER

Horag Choi

Monash University

First Draft: February 2015

\begin{abstract}
We study empirically and theoretically the dynamics of the US trade balance. We propose a theoretical decomposition of fluctuations in the trade balance into terms related to trade integration (global and unilateral) and terms related to asymmetries in the business cycle. We find three main results. First, the relatively large trade deficits as a share of GDP of the US in the 2000s compared to the 1980s mostly reflect a rise in trade share of GDP. Second, between 40 and 80 percent of the fluctuations in ratio of the trade balance to trade reflects an uneven pace of trade liberalization. Third, while asymmetries in the business cycle account for 20 to 60 percent of fluctuations in the trade balance over trade, over two-thirds of the business cycle induced movements in net trade flows are a lagged response to changes in the terms of trade and real exchange rate. That is, the short-run Armington elasticity is about 0.15 while the long-run is closer to 1.7 with only 7 percent of the gap closed per quarter. Constant elasticity models of trade explain less than 10 percent of the movements in the trade balance.
\end{abstract}

JEL classifications: E31, F12.

Keywords: Trade Balance, Real Exchange Rate, International Business Cycles.

*George.Alessandria@Rochester.edu; Horag.Choi@monash.edu. We thank audiences at the Banque de France, Philadelphia Fed, Rochester and SED for helpful comments. 


\section{Introduction}

What leads a country to run a trade deficit or surplus? The traditional view is that these imbalances reflect differences in the business cycle from productivity, monetary, or fiscal shocks. In this paper, we show a surprisingly large share of fluctuations in the ratio of the trade balance to GDP over time actually reflect trade integration, both global and local, rather than asymmetries in business cycles across countries. We propose a simple theoretical decomposition of the trade balance into terms related to trade integration (both global and unilateral) and a term related to asymmetries in business cycles (from relative prices and relative expenditures). We then build a model of trade integration and the business cycle and use it to evaluate the contribution of trade integration and business cycles to the dynamics of the US trade balance.

To set ideas, figure 1 plots two salient features of the US economy's connection with the rest of the world: rising trade deficits and rising trade. First, the US trade balance shows two cycles with different amplitudes. For instance, in the 1980s the US trade deficit as a share of GDP peaked in 1986q3 at 2.6 percent. Twenty years on, it peaked at 5.6 percent of GDP. In both cases, the maximum trade deficit lagged the peak real exchange rate by about 6 quarters and the peak real exchange rates were of roughly similar magnitude. Second, the near doubling of the peak of the US trade deficit across these two periods occurred as trade doubled from 13.1 percent of GDP to 26.1 percent.

We seek to sort out whether the much larger trade deficit of 2006, and the second cycle more generally, reflects greater substitution between domestic and foreign tradables or growing integration. To make this point clear, we decompose the movements in the trade deficit to GDP ratio into the movements in the ratio of trade balance to trade (TBTR) and trade to GDP (TRY),

(1) $T B Y=\frac{X-M}{X+M} \frac{X+M}{Y}=T B T R * T R Y$. 
Figure 2 plots the US trade deficit to GDP ratio and a counterfactual US trade deficit with the same trade share as 1986. Not surprisingly, holding trade constant at its 1986 level leads to a peak trade deficit in 2006 of only 2.7 percent, almost the same in 1986 . The amplitude of the more recent cycle in the trade balance is of similar magnitude to the 1980 s cycle. This suggests that the movements in the trade balance as a share of overall trade where about the same in 2006 as in 1986.

Trade integration also contributes to fluctuations in the ratio of the trade balance to trade ratio. We propose a simple theoretical decomposition of the trade balance to trade ratio into terms related to uneven trade integration and differences in the business cycle that builds on the Armington CES structure. Our decomposition extends the trade wedge accounting approach of Levchenko, Lewis and Tesar (2010) and Alessandria, Kaboski, and Midrigan (2013). The business cycle component is determined by relative expenditures, relative prices (both the terms of trade and real exchange rate), and the Armington elasticity. We undertake this analysis explicitly taking into account the well-known idea that the trade balance takes time to respond to movements in the real exchange rate and terms of trade. Indeed, a contribution of this paper is to estimate the short-run and long-run Armington elasticity along with the speed of adjustment and evaluate the role of these different elasticities on the dynamics of the trade balance.

Our two decompositions of the trade balance to gdp, provide an empirical decomposition of the dynamics in the US trade balance. We find three main results. First, the relatively large trade deficits as a share of GDP of the US in the 2000s compared to the 1980s mostly reflects a rise in the trade share of GDP. Indeed, holding trade constant at the level from the 1980s would have reduced the average trade deficit roughly in half. Second, about 40 percent of the fluctuations in the ratio of the trade balance to trade reflect an uneven pace of trade liberalization. Third, while asymmetries in the business cycle, as reflected in movements of relative production and relative prices, account for the remaining 60 percent of fluctuations 
in the trade balance over trade, almost $2 / 3$ of the business cycle induced movements in net trade flows are a lagged response to asymmetries in the business cycle. A simple way of seeing this is that the short-run Armington elasticity is about 0.15 while the long-run is closer to 1.65 and only about 6.6 percent of the gap gets closed each quarter. ${ }^{1}$ Ignoring the gradual response of trade to relative price movements, reduces the importance of the business cycle (and increases the importance of uneven trade liberalizations) to about 20 percent (80) percent of the fluctuations in the trade balance to trade ratio.

Our empirical exercise provides an accounting of the timing of trade integration. As in Levchenko, Lewis, and Tesar, (2010), Alessandria, Kaboski and Midrigan, (2013) we recover US import trade wedges. Unlike these other papers, we also measure the wedge on ROW imports from the US. Starting in 1980, these wedges show that foreign trade integration grew faster than that in the US, but some time in the early 2000s foreign integration actually reversed while the pace of US integration slowed. Since the Great Recession, it appears that trade integration has reversed in the ROW and stagnated in the US.

To address the features of the trade balance and international business cycles we build on the heterogeneous producer model of Alessandria and Choi (2007). This is a variation of the Backus, Kehoe, and Kydland (1994) international real business cycle model with heterogenous producers subject to idiosyncratic productivity shocks and a sunk and fixed cost of exporting as in Dixit (1989), Baldwin and Krugman (1989), and Das, Roberts and Tybout (2007). The heterogeneity and dynamic exporting decision leads exporters to respond gradually to aggregate shocks. We extend the model along two dimensions. First, we introduce pricingto-market by allowing the elasticity of substitution to vary with the real exchange rate. We parameterize this so that when a country's price level appreciates, its exporters lower their markup by as much as we tend to observe in the data. Pricing-to-market is crucial to explain the persistent deviations from the law of one price across countries and to get

\footnotetext{
${ }^{1}$ These elasticities are about twice as large when we focus only on trade in goods excluding oil.
} 
the real exchange rate to fluctuate more than the terms of trade as in data (see Alessandria 2009). Additionally, pricing-to-market leads US firms to raise their markups when the US real exchange rate depreciates. These higher markups lead to a stronger expansion of US exporters than in the constant markup case. Second, we introduce shocks to the costs of trade in each country. The persistent component of trade costs is chosen to match the more than doubling of US trade-to-GDP ratio from the 80s. The temporary shocks to trade costs are chosen to capture the highly cyclical nature of trade, particularly around turning points of the economy. Through a series of numerical exercises we show that uneven changes in trade integration can generate large and persistent movements in the trade balance, real exchange rate, and relative expenditures.

We then apply the model to re-consider the contribution of asymmetric trade shocks to fluctuations in the trade balance to trade ratio. We find that about 30 percent of the fluctuations in the trade balance to trade ratio since 1980 are attributable to uneven trade integration. This number though hides some important variation over time. For instance, since 2012 the uneven trade shocks account for more than half of the US trade deficits.

This paper is related to models of international transmission with flexible and sticky prices such as Backus, Kehoe and Kydland (1994), Chari, Kehoe and McGrattan (2002) and Corsetti, Dedola and Leduc (2008). The paper is most closely related to models with a different short-run and long-run trade response (Alessandria and Choi (2007), Drozd and Nosal (2011), Engel and Wang (2012), Alessandria, Pratap and Yue (2011) and Imura (2013). This paper is also related to models that consider trade costs in aggregate fluctuations (Levchenko, Lewis, and Tesar, 2010, Alessandria, Kaboski and Midrigan, 2010, 2011, 2013, Eaton, Kortum, Neiman and Romalis, 2014). This paper is also related the literature that seeks to estimate trade elasticities. Similar to Hooper, Marquez, and Johnson (2000), we an estimate error correction models of trade flows, but unlike that paper we focus on net trade flows. Gallaway, McDaniel and Rivera (2003) estimate these at the industry level, and find that 
long-run elasticities are generally two to three times short-run trade elasticities. This paper also contributes to the recent literature on global imbalances (Caballero, Farhi, and Gourinchas, 2008) and the adjustment required to close these imbalances (Obstfeld and Rogoff, 2005 , Dekle, Eaton, and Kortum, 2008). A key conclusion of our analysis is that the same theory of trade balance dynamics can explain the 1980's and 2000's US trade balance dynamics.

In section 2, we focus on decomposing the source of fluctuations in the trade balance. In section 3, we build a two country general equilibrium model of endogenous trade participation, trade integration, and the business cycle. In section 4, we examine the properties of the model in response to changes in trade costs and productivity. Section 5 concludes.

\section{Evidence}

In this section we extend the simple decomposition from equation 1 to include some theoretical structure. This theoretical structure is used to relate the conventional view of the determinant of the comovement between the real exchange rate and trade balance from Backus, Kehoe and Kydland (1994) to our findings. We then estimate the key parameters of the theoretical model determining the trade balance. The estimated model is used to decompose the fluctuations in the US trade balance. Finally, we present the inferred shocks to trade integration.

The simple decomposition of the trade balance in equation 1 is easy to extend to include the Armington trade model common to multi-country trade models of integration and business cycles. In the Armington trade model with home and foreign goods that are imperfect substitutes the ratio of exports to imports is described by the following structural relationship

$$
\ln (X / M)=\ln \left(\omega^{*} / \omega\right)-\rho\left[\ln \left(P_{x}\left(1+\tau^{*}\right) / P^{*}\right)-\ln \left(P_{m}(1+\tau) / P\right)\right]+\ln \left(D^{*} / D\right)
$$

where $\rho$ is the elasticity of substitution between home and foreign goods, $\tau, \tau^{*}$ are trade costs/taste shifters, $P_{x}$ and $P_{m}$ are the export and import prices, $P, P^{*}$ are the home and 
foreign price levels, $D, D^{*}$ denote home and foreign domestic absorption. It is straightforward to show that

$$
\ln (X / M) \approx 2 T B T R=2 \frac{X-M}{X+M}
$$

so that we can decompose the trade balance in the following way ${ }^{2}$

$$
T B Y \approx 0.5 \ln (X / M) * T R Y
$$

For our purposes it is useful to combine the changes in trade costs and tastes together into $\mathrm{T}^{*}, \mathrm{~T}$ and define the terms of trade and real exchange rate as

$$
\text { TOT }=P_{m} / P_{x} \text { and } R E R=P^{*} / P
$$

and then rewrite our equation as

$$
\ln (X / M)=\ln \left(T^{*} / T\right)+\rho[T O T+R E R]+\ln \left(D^{*} / D\right)
$$

This provides a simple decomposition of the trade ratio into changes in trade costs, substitution from relative prices, and relative expenditures.

This key equation also sheds light on the famous "S-curve" result from Backus, Kehoe, and Kydland (1994) that echoes an earlier literatures emphasis on the J-curve. They show that the tendency for the trade balance to decrease initially and then gradually increase following a depreciation of the real exchange rate ${ }^{3}$ is well-described by a two country dynamic stochastic general equilibrium model with productivity shocks and capital accumulation. ${ }^{4,5}$ In that model a positive productivity shock leads both to a depreciation of the real exchange

\footnotetext{
${ }^{2}$ This measure overstates the maximum deficit by 0.4 percentage points (22.7 percent vs 23.1 percent).

${ }^{3} \mathrm{BKK}$ focus on the dynamics between the trade balance and the terms of trade not the real exchange rate. However, in their framework the terms of trade and real exchange rate are perfectly correlated.

${ }^{4}$ Raffo (2008) points out that in the BKK model that real trade balance to gdp ratio and nominal trade balance to gdp are negatively correlated when investment is constrained to match the observed pattern in the data while in the data they are quite positively correlated. By making consumption more volatile he can fix this problem.

${ }^{5}$ Heathcoate and Perri (2014) use this model as the benchmark for international business cycles in the recent handbook of international economics chapter.
} 
rate and a trade deficit. The cross country productivity gap lowers the price of the home good yielding a depreciation while temporarily stimulating investment leading to a trade deficit.

The apparent success of the two country RBC model in explaining the comovement between the trade balance and the real exchange rate is actually rooted in its two well-known failures: the quantity and price puzzles. The quantity puzzle is the inability of the model to generate synchronized business cycles. The price puzzle is the inability of the model to generate large enough relative price movements. Whenever the real exchange rate depreciates, say from an increase in productivity, this makes the ratio of exports to imports increase. To generate a trade deficit with a depreciation then requires the second term, which is the difference in foreign and domestic expenditures, to respond strongly to offset the substitution effect. Taken together the quantity and price puzzles make the expenditure effect quite strong and the substitution effect weak. With a strong but temporary gap in cross country expenditures the ratio of expenditures will move from deficit to surplus over time explaining the gradual response of the trade balance following the depreciation.

By controlling for movements in relative expenditures it is straightforward to see that the trade-expenditure ratio equals

$$
\ln (X / M)-\ln \left(D^{*} / D\right)=\ln \left(T^{*} / T\right)+\rho[T O T+R E R]
$$

With this in hand, it is clear that once one controls for movements in relative expenditures all that is left is the substitution effect and so a depreciation will always lead to a surplus in this alternative measure of the net trade flows. Moreover, correlations of the left hand side with lags of the real exchange rate will equal to the autocorrelation of the trade-expenditure ratio.

To evaluate the determinants of the fluctuations in the trade ratio we estimate equation 3, where now $\ln \left(T^{*} / T\right)$ can be interpreted as a combination of trade integration shocks plus a residual. Table 1 reports the results of three types of regressions, in first differences, levels, 
and first differences with an error correction term. ${ }^{6}$ We also report the results when we control for net inventory investment as suggested by Alessandria, Kaboski and Midrigan (2011). All coefficients are quite significant. We find that the Armington elasticity is quite low in the short run, between 0.15 and 0.18 . The level regression suggests an elasticity closer to 0.53 , but this mixes the short-run and long-run. The error correction model suggests a short run elasticity of 0.14 and a long-run elasticity of 1.65 with 6.5 percent of the gap between the current net export ratio of the long-run closed each quarter. ${ }^{7}$

The fit of the empirical model of changes in the trade-expenditure ratio rises from 4.7 percent in differences to 28.1 percent in our short-run/long-run model. The relatively poor fit of the empirical models suggests there are substantial movements in the trade-expenditure ratio that are related to trade integration. These shocks could reflect a different pace of liberalization (contemporaneous and lagged effects) or perhaps inventory type considerations (see Alessandria, Kaboski, and Midrigan, 2011 and 2013). Indeed, we find that the fit of the regression is slightly better when we control for inventory investment, ${ }^{8}$ but the Armington elasticity is essentially unchanged. While inventory considerations are a reasonable source of short-run trade wedges, they do not account for the long-run changes in the wedges we observe. The much better fit of the SR/LR model (error correction) suggest that most of the effect of relative prices occurs only gradually.

The estimated coefficients from the regression of changes in the trade-expenditure ratio are used to come up with a predicted path of the trade-expenditure ratio. Figure 3 plots the predicted trade-expenditure ratio from the data and these three statistical models along with the US real exchange rate. The error correction model clearly captures the gradual movements

\footnotetext{
${ }^{6}$ The error correction model is $d . n x r d d=d . t o t+l . n x r d d+l . t o t$ where nxrdd is the dependent variable, tot is the relative price term, $\mathrm{d}$ denotes difference and $l$ denotes lag.

${ }^{7} \mathrm{We}$ also run the regressions allowing the coefficient on relative expenditure to differ from 1 in the shortrun. This generally improves the fit but has a minimal impact on our estimate of the Armington elasticity.

${ }^{8}$ The full effect of inventories on trade is understated by our measure of inventories since this is the total change in inventories and not that change in imported inventories.
} 
in the trade-expenditure ratio to movements in the real exchange rate. In particular, the delayed response of the trade-expenditure ratio to the Plaza Accord and the depreciation of the dollar in the early 2000's are quite evident.

Table 2 reports how well these models explain the movements in the trade-expenditure ratio. To construct a trade-expenditure measure from the models estimated on changes we accumulate the changes. To measure the fit of the model in differences we chose the mean of these series to minimize the sum of squared residuals between the model and data. ${ }^{9}$ Not surprisingly, the SR/LR elasticity model captures between 2.2 to 3 times as much of the variation in our trade-expenditure ratio measure as the constant elasticity models (59.6 percent vs 21.2 to 25.9 percent).

Focusing just on the trade ratio by adding back in the differences in expenditures, boosts the contribution of the business cycle slightly to 62.5 percent for the SR/LR model and 26.7 to 31.1 percent for the constant elasticity model. The small additional role of the business cycle arises because business cycles are quite synchronized in the data and thus the gap in expenditures/production across countries never is very large compared to the movements in the real exchange rate, reinforcing our explanation of why the standard IRBC model generates fluctuations in the trade balance through a counterfactual mechanism - quite asymmetric business cycles.

We attribute the movements of the trade ratio that are not explained by the movements in relative prices or relative expenditures as arising from asymmetric trade integration shocks. Thus depending on our empirical model, uneven trade liberalization explains between 40 and 73 percent of the fluctuations in the export ratio.

Table 3 reports the average US trade deficit in the data since 1991 and a counterfactual holding the share of GDP in trade at its 1986 level. Without trade growth, the average US

\footnotetext{
${ }^{9}$ This perhaps overstates the importance of the model in differences since it assumes the US is running a permanent trade deficit.
} 
trade deficit would have been slightly more than half as big (1.58 percent vs 2.95$)$. Attributing the gap between the data and this counterfactual to trade integration, suggests that just under half of the average US trade deficit since 1991 was due to increased multilateral trade integration.

Table 4 combines the results of the previous two tables to decompose the source of fluctuations in the trade balance to GDP from 1991 to $2014 .{ }^{10}$ Trade integration has been the main driver of fluctuations in the trade balance, accounting for between 66 and 85 percent of US trade deficits.

\section{Trade Wedges and the pace of integration}

Our empirical analysis concludes with a presentation of the inferred trade wedges. This provides a sense of the dynamics of integration. So far, our empirical work yields the gap in the ROW and US trade wedge. To actually come up with a series for the level of trade wedges in each country, we use our coefficient estimates and solve for the trade wedge as a residual.

Figure 4 plots the gap in the trade wedges for the three models along with the trade ratio. Each wedge is demeaned over the window. Not surprisingly, the gap in the wedge across countries from the error correction model is much smoother than the other two models.

Figure 5 plots the home and foreign wedge since 1980 that comes from the empirical dynamic trade model. A few interesting points are evident. First, trade integration was fairly steady until the early 2000's but has stagnated since. Second, initially trade integration was roughly balanced, but in the late 80 s foreign liberalization picked up relative to that in the US. Since, the mid 2000s foreign liberalization has regressed relative to the US. Indeed, it appears that trade integration has reversed somewhat since the mid 2000s.

\footnotetext{
${ }^{10}$ This is a decomposition of the source of fluctuations in the trade-balance to gdp coming from the accounting identity. It is in no way attributing the fluctuations in the trade balance to particular shocks. We will use the model to decompose the shocks leading to these fluctuations.
} 


\section{Model}

We now develop a two country model with heterogenous producers entering and exiting the export market. We extend the model of Alessandria and Choi (2007) to include shocks to trade costs and variables markups. We use the model to evaluate the impact of symmetric and asymmetric changes in trade costs on the aggregate economy.

Home and foreign prices are normalized to $1: P_{t}=P_{t}^{*}=1$.

Consumers: Consumers maximize the discounted sum of utility. They trade a noncontingent bond with the ROW. THe

$$
\max E_{0} \sum_{t=0}^{\infty} \Theta_{t} U\left(C_{t}, L_{t}\right),
$$

subject to

$$
C_{t}+V_{t} B_{t}=W_{t} L_{t}+B_{t-1}+\Pi_{t}
$$

where $U(C, L)=\left[C^{\gamma}(1-L)^{1-\gamma}\right]^{1-\sigma} /(1-\sigma), \Pi_{t}$ is the dividend payments from home firms. In a standard model with $\Theta_{t}=\beta^{t}$, we apply small bond holding cost of $\frac{\zeta_{b}}{2}\left(\frac{V_{t} B_{t}}{Y_{t}^{N}}\right)$ for home with $Y_{t}^{N}$ being nominal home GDP and $\frac{\zeta_{b}}{2}\left(\frac{V_{t} B_{t}^{*}}{q_{t} Y_{t}^{N *}}\right)$ for foreign.

The stochastic cumulative discount factor evolves as

$$
\begin{aligned}
\ln \left(\Theta_{t+1} / \Theta_{t}\right) & =\ln \beta_{t} \\
& =\left(1-\rho_{b}\right) \ln \bar{\beta}+\rho_{b} \ln \beta_{t-1}-\psi\left(\ln \widetilde{C}_{t}-\ln \bar{C}\right)
\end{aligned}
$$

where $\bar{\beta}$ is the steady state $\beta, \bar{C}$ is the steady state $C$, and $\widetilde{C}_{t}$ is the average (aggregate) consumption in the economy. Thus, the discount factor $\beta_{t}$ is external. 
Aggregation Technology or Consumption Index: A competitive retail sector combines a continuum of domestic goods and the available imported goods to produce the final good. The aggregators are as follows:

$$
\begin{aligned}
D_{t} & =\left(Y_{H t}^{\frac{\rho-1}{\rho}}+a^{\frac{1}{\rho}} Y_{F t}^{\frac{\rho-1}{\rho}}\right)^{\frac{\rho}{\rho-1}}, \\
Y_{H t} & =\left(\int_{0}^{1} Y_{h i t}^{\frac{\theta-1}{\theta}} d i\right)^{\frac{\theta}{\theta-1}}, \\
Y_{F t} & =\left(\int_{i \in \mathcal{E}_{t}^{*}} Y_{f i t}^{\frac{\theta_{t}-1}{\theta_{t}}} d i\right)^{\frac{\theta_{t}}{\theta_{t}-1}} .
\end{aligned}
$$

The elasticity of substitution for imported goods is allowed to be time varying, $\theta_{t}=\theta q_{t}^{\zeta}$ with $q_{t}$ being the real exchange rate in terms of home aggregate (a rise in $q$ means real depreciation of home). This is a parsimonious way of embedding pricing-to-market. It can be microfounded using search frictions as in Alessandria (2009), Alessandria and Kaboski (2011), or Drozd and Nosal (2013). The price indices for the aggregates are

$$
\begin{aligned}
P_{H t} & =\left(\int P_{h i t}^{1-\theta} d i\right)^{\frac{1}{1-\theta}}, \\
P_{F t} & =\left(\int_{i \in \mathcal{E}_{t}^{*}} P_{f i t}^{1-\theta_{t}} d i\right)^{\frac{1}{1-\theta_{t}}}, \\
P_{t} & =\left(P_{H t}^{1-\rho}+a P_{F t}^{1-\rho}\right)^{\frac{1}{1-\rho}}=1 .
\end{aligned}
$$

In equilibrium $D_{t}=C_{t}$.

Firms: We follow Alessandria and Choi (2007) and model the firm as facing idiosyncratic and aggregate shocks to productivity and fixed trade costs. 
The production function of a firm is given by

$$
Y_{i t}=e^{Z_{t}+\eta_{i t}} L_{i t},
$$

where $Z_{t}$ is the country-wide productivity, $\eta_{i t}$ is the firm specific productivity with $\eta_{i t} \stackrel{i i d}{\sim}$ $N\left(0, \sigma_{\eta}^{2}\right)$. The country productivity follows

$$
\left[\begin{array}{c}
Z_{t} \\
Z_{t}^{*}
\end{array}\right]=A_{z}\left[\begin{array}{c}
Z_{t-1} \\
Z_{t-1}^{*}
\end{array}\right]+\left[\begin{array}{c}
\varepsilon_{Z t} \\
\varepsilon_{Z t}^{*}
\end{array}\right], \quad\left[\begin{array}{c}
\varepsilon_{Z t} \\
\varepsilon_{Z t}^{*}
\end{array}\right] \stackrel{i i d}{\sim} N\left(0, \Sigma_{Z}\right)
$$

Exporting costs are given by $W_{t} f_{0}$ for starters, and $W_{t} f_{1}$ for continuing exporters. The (gross) marginal trade cost is given by $\xi_{t}^{*}$ for home exporters, and $\xi_{t}$ for foreign exporters. The resource constraint for each good is given by

$$
Y_{i t}=Y_{h i t}+m_{i t} \xi_{t}^{*} Y_{h i t}^{*}
$$

where $m_{i t}$ is the exporting status of firm $i$. The marginal trade cost is stochastic with

$$
\left[\begin{array}{c}
\ln \xi_{t} \\
\ln \xi_{t}^{*}
\end{array}\right]=A_{\xi}\left[\begin{array}{l}
\ln \xi_{t-1} \\
\ln \xi_{t-1}^{*}
\end{array}\right]+\left[\begin{array}{c}
\varepsilon_{\xi t} \\
\varepsilon_{\xi t}^{*}
\end{array}\right], \quad\left[\begin{array}{c}
\varepsilon_{\xi t} \\
\varepsilon_{\xi t}^{*}
\end{array}\right] \stackrel{i i d}{\sim} N\left(0, \Sigma_{\xi}\right)
$$

It is well known that when $W_{t} f_{0}>W_{t} f_{1}$, the decision to export is forward looking and that the distribution of exporters in each country is a state variable. It is also well-known that there is a threshold technology for exporters to continue exporting $\left(z_{1 t}\right)$ and a second threshold technology for non-exporters to start exporting $\left(z_{0 t}\right)$. Firms doing a will move in and out of the export market in response to shocks to idiosyncratic and aggregrate shocks.

Aggregate Varia of thebles: The nominal output (GDP) is given by

$$
Y_{t}^{N}=\int\left(P_{h i t} Y_{H i t}+q_{t} P_{h i t}^{*} Y_{H i t}^{*}\right) d i
$$


The real GDP is given by

$$
Y_{t}^{R}=\frac{Y_{t}^{N}}{P_{H t}} .
$$

The nominal export is given by

$$
\begin{aligned}
E X_{t}^{N} & =\int q_{t} P_{h i t}^{*} Y_{h i t}^{*} d i \\
& =a q_{t} P_{H t}^{* 1-\rho} D_{t}^{*}
\end{aligned}
$$

The export price index is given by

$$
P_{X t}=\frac{q_{t} P_{H t}^{*}}{\xi_{t}^{*}} .
$$

The real export is given by

$$
\begin{aligned}
E X_{t}^{R} & =\frac{E X_{t}^{N}}{P_{X t}} \\
& =a \xi_{t}^{* 1-\rho} q_{t}^{\rho} P_{X t}^{-\rho} D_{t}^{*} .
\end{aligned}
$$

The nominal import is given by

$$
\begin{aligned}
I M_{t}^{N} & =\int P_{f i t} Y_{f i t} d i \\
& =a P_{F t}^{1-\rho} D_{t} .
\end{aligned}
$$

The import price index is given by

$$
P_{M t}=\frac{P_{F t}}{\xi_{t}} .
$$

The real import is given by

$$
\begin{aligned}
I M_{t}^{R} & =\frac{I M_{t}^{N}}{P_{M t}} \\
& =a \xi_{t}^{1-\rho} P_{M t}^{-\rho} D_{t} .
\end{aligned}
$$


We define the terms of trade as

$$
\operatorname{TOT}_{t}=\frac{P_{M t}}{P_{X t}}
$$

So, we have

$$
\ln \left(E X_{t}^{R} / I M_{t}^{R}\right)=(\rho-1) \ln \left(\xi_{t} / \xi_{t}^{*}\right)+\rho\left(\ln q_{t}+\ln T O T_{t}\right)+\ln \left(D_{t}^{*} / D_{t}\right)
$$

The trade balance to GDP ratio is given by

$$
N X Y_{t}=\frac{E X_{t}^{N}-I M_{t}^{N}}{Y_{t}^{N}} .
$$

\section{Calibration}

The time period is a quarter and so we set $\beta=0.99$. The risk aversion parameter, $\sigma=2$. The weight on leisure is set so that hours worked is equal to a $1 / 4$. The bond adjustment cost is set to 0.0001 and the externality on the discount factor is set to 0.005 . The trade $\operatorname{costs}\left(f_{0}, f_{1}\right)$ and standard deviation of shocks $\left(\sigma_{\eta}\right)$ and the weight in the aggregator are chosen so that trade is $10 \%$, export participation is 20 percent, the quarterly exporter exit rate is 2.5 percent, and exporters are 50 percent larger than non-exporters. The elasticity of substitution is set to 4 , while the Armington elasticity is set to 1.65, essentially equal to our long-run elasticity. The pricing-to-market parameter is chosen to generate 50 percent pass-through (Goldberg and Knetter, 1997).

\section{Results}

We now examine the aggregate impact of changes in trade integration. As our main interest is in examining the impact of trade integration on the dynamics of the trade ratio, we consider transitory asymmetric shocks to trade costs. These asymmetric movements in

trade costs generate fluctuations in the trade balance to GDP ratio, the trade ratio, and the 
real exchange rate. We first consider the impact of the path of uneven trade integration on the US trade ratio. Then, we explore the aggregate impact of a decline in the iceberg cost for delivering products to the home market.

To examine the impact of asymmetric trade costs on the US trade ratio, the model economy is hit with the relative shocks inferred from trade ratio. We split the differential wedge equally between home and foreign trade costs. The shocks are assumed to have an autocorrelation of 0.965 as in the data.

Figure 6 plots the gap in the trade wedge and the trade-ratio in the model and the data. The top panel shows that the trade wedge in the model tracks that inferred from the data. The fit need not be perfect since we are using production as a measure of expenditure, but it is generally quite good. The bottom panel shows that the trade-ratio from the wedge shocks fluctuates considerably less than the trade-ratio in the data. The differential pace of integration was influential in the shrinking of the trade deficit in the 1980s, while the differential pace of integration since the mid 90 s has lead to substantially larger trade deficits. Indeed, at the end of the sample, we see that since the Great Recession that the trade ratio would have moved closer to balance without the differential trade costs and that nearly half of the deficit in 2014 is due to differential trade costs. Table 6 reports a variance decomposition of the trade-ratio. It shows that the asymmetric shocks account for 27.4 .6 to 30.2 percent of the fluctuations in the trade ratio, depending on the period. These are sizeable, but not nearly as important as our empirical work indicates.

Figure 7 considers the dynamics of the trade ratio when we eliminate the externality on the discount factor and pricing-to-market. Eliminating the externality reduces the contribution of asymmetric trade integration shocks by about 60 percent, to 12.6 to 13.2 percent, again depending on the period. Eliminating pricing-to-market reduces the variance of the trade ratio half again so that they now account for 5 to 6 percent of the fluctuations in the trade ratio. 
To understand these results, we consider various parameterizations of the model, and always choose the size of the shock to generate a 1 percentage point increase in the home trade share on impact.

Figure 8 plots the impact of a decline in the home iceberg cost when the persistence is 0.95. The trade share expands 1 percentage point on impact and then gradually mean reverts. The trade share mean reverts more slowly than the shock owing to an expansion in home export participation. The shock generates a home deficit of about 0.30 percent of GDP on impact. The trade deficit turns to surplus gradually. These dynamics are largely driven by the movements in the trade ratio. The real exchange rate depreciates sharply, by about 3.25 percent and gradually mean reverts.

Figure 9 plots the impact with a less persistent shock with an autocorrelation of 0.75 . This shock generates a larger trade deficit of almost 0.55 percent of GDP. The trade deficit is not as persistent, turning to a surplus four quarters later. The real exchange rate depreciates by 3 percent.

Figure 10 plots the impact of a decline in the home iceberg cost when the persistence is 0.95 and we boost the trade elasticity to 3.3. The trade share expands 1 percentage point on impact and then gradually expands further, peaking at 1.31 percent 5 quarters later. The shock generates a home deficit of about 0.25 percent of GDP on impact. The trade deficit turns to surplus gradually. These dynamics are largely driven by the movements in the trade ratio. The real exchange rate depreciates sharply, by about 1.5 percent and gradually mean reverts. The home and foreign country export participation expands, but the home country expands by more owing to the depreciation.

Figure 11 plots the case with a trade elasticity to 0.55 . Now, to get trade to increase we need to actually increase trade costs. Once again, the economy runs a persistent nominal trade deficit, but in real terms it immediately runs a surplus. The real exchange rate depreciates by almost 4 percent and remains elevated. Home export participation gradually expands while 
foreign export participation declines. The participation decisions imply that the real trade balance grows gradually, peaking almost 30 quarters after the shock and almost 20 quarters after the real exchange rate.

\section{Summary}

We present evidence that a substantial fraction of the fluctuations in the US trade balance as a share of GDP reflect global and unilateral movements towards greater trade integration. Indeed, the relatively large trade deficits to GDP of the 2000s compared to the 1980s mostly reflect mostly an expansion of trade rather than an increase in the substitution between imported and domestic products over the business cycle. We actually find that, if anything, the imbalances were relatively small compared to the movements in relative prices and relative expenditures.

We present empirical evidence on the contribution of the business cycle and trade integration on the trade balance. Depending on our empirical model, we find that the traditional source of movements in trade balance, relative prices and relative expenditure movements, account for at most one-third of the movements in the trade balance, with most of the movements due to movements in the terms of trade and real exchange rate. We also show that two-thirds of the contribution of relative prices to trade balance arise from gradual trade dynamics.

Our empirical work makes clear that standard models of the international business cycle with a constant Armington elasticity, despite their pervasiveness ${ }^{11}$, are ill-suited to explain the cyclical behavior of trade balance. We suggest more work should be done with models with endogenous trade participation arising from a dynamic decision and fluctuations in trade costs. We take a first step in this direction by analyzing the aggregate effect of persistent, asymmetric changes in trade costs in a dynamic trade model. We find that these asym-

\footnotetext{
${ }^{11}$ See the recent handbook chapter by Heathcoate and Perri (2014).
} 
metric trade shocks can generate sizeable movements in the trade balance, although more quantitative work remains to be done. 


\section{Data}

Recall that our main equation is

$$
\ln (X / M)=\ln \left(\omega^{*} / \omega\right)-\rho\left[\ln \left(P_{x}\left(1+\tau^{*}\right) / P^{*}\right)-\ln \left(P_{m}(1+\tau) / P\right)\right]+\ln \left(D^{*} / D\right),
$$

- D is proxied by US Industrial Production Index (SA, 2007=100) (FRB )

- $\mathrm{D}^{*}$ is proxied by a US trade weighted Advanced Economies Industrial Production (Dallas Fed)

- $\mathrm{P} / \mathrm{P}^{*}$ is measured as the Real Broad Trade-Weighted Exchange Value of the US\$ (Mar$73=100)(\mathrm{FRB})$

- X Real Exports of Goods \& Services (SAAR, Bil.Chn.2005\$) (BEA)

- M Real Imports of Goods \& Services (SAAR, Bil.Chn.2005\$) (BEA)

- $\mathrm{P}_{X}$ Exports of Goods \& Services: Chain Price Index (SA, 2005=100) (BEA)

- $\mathrm{P}_{M}$ Imports of Goods \& Services: Chain Price Index (SA, 2005=100) (BEA)

- NII is Real Net Inventory Investment (SAAR, Bil.Chn.2005\$) (BEA)

- To measure the US trade wedge on imports we use the BEA's consumption price deflator (Consumption : Chain Price Index (SA, 2005=100)*/)

- Time period 1980q1 to 2014q3. 


\section{References}

Alessandria, George and Horag Choi, 2007. "Do Sunk Costs of Exporting Matter for Net Export Dynamics?" Quarterly Journal of Economics, 122(1), 289-336.

— , 2014a. "Establishment Heterogeneity, Exporter Dynamics, and the Effect of Trade Liberalization." Journal of International Economics.

— , 2014b. "Do Falling Iceberg Costs Account for Recent US Export Growth?" Journal of International Economics.

Alessandria, G., J. Kaboski, and V. Midrigan, 2013. "Trade Wedges, Inventories, and International Business Cycles," Journal of Monetary Economics, 60(1), 1-20.

Alessandria, G., S. Pratap and V. Yue. 2011. "Export Dynamics in Large Devaluations," mimeo.

Backus, David, Patrick Kehoe, and Finn Kydland, "Dynamics of the Trade Balance and the Terms of Trade: The J Curve?" American Economic Review, LXXXIV (1994), 84-103.

Baldwin, Richard and Paul Krugman, 1989. "Persistent Trade Effects of Large Exchange Rate Shocks," Quarterly Journal of Economics, 104(4), 821-854.

Caballero, Ricardo J., Emmanuel Farhi, and Pierre-Olivier Gourinchas. 2008. "An Equilibrium Model of "Global Imbalances" and Low Interest Rates." American Economic Review 98:1, 358-393.

Das, Sanghamitra, Mark Roberts, and James Tybout, 2007. "Market Entry Costs, Producer Heterogeneity, and Export Dynamics," Econometrica, 75(3), 837-873.

Dixit, Avinash K., "Hysteresis, Import Penetration, and Exchange Rate Pass-Through," Quarterly Journal of Economics, CIV (1989a), 205-228.

— , "Entry and Exit Decisions Under Uncertainty," Journal of Political Economy, XCVII (1989b), 620-638.

Dekle, R., Eaton, J., S. Kortum, 2008. "Global Rebalancing with Gravity: Measuring the Burden of Adjustment,"IMF Staff Papers, 55(3), 511-40.

Eaton, Kortum, Neiman and Romalis, 2014. "Trade and the Global Recession."

Drozd, Lukasz and Jaromir Nosal, 2012. "Understanding International Prices: Customers as Capital," American Economic Review, Vol. 102 (1).

Engel, Charles and Jian Wang. 2011. "International Trade in Durable Goods: Understanding Volatility, Cyclicality, and Elasticities," Journal of International Economics, 83(1), 37-52.

Gallaway, Michael P., Christine A. McDaniel, Sandra A. Rivera. 2003. "Short-run and longrun industry-level estimates of U.S. Armington elasticities" North American Journal of Economics and Finance 14, 49-68. 
Heathcoate, J. and F. Perri. 2014. "Assessing International Efficiency", Handbook of International Economics.

Hooper, P., K. Johnson and J. Marquez, 2000. "Trade Elasticities for G-7 Countries,"Princeton Studies in International Economics No. 87 (Princeton University Press: Princeton NJ).

Junz, Helen and Rudolf Rhomberg, 1973. "Price Competitiveness in Export Trade Among Industrial Countries." American Economic Review, 63(2), 412-418.

Magee, Steven, 1973. "Currency Contracts, Pass-through and Devaluations," Brookings Papers on Economic Activity. 1973(1), 303-325.

Meade, Ellen, 1988. "Exchange Rates, Adjustment, and the J-Curve." Federal Reserve Bulletin, 74(10): 633-644.

Obstfeld, Maurice and Kenneth Rogoff (2005). "Global Current Account Imbalances and Exchange Rate Adjustments." Brookings Papers on Economic Activity 1: 67-146.

Roberts, Marks and James Tybout, 1997. "The Decision to Export in Colombia: An Empirical Model of Entry with Sunk Costs," American Economic Review, 87(4), 545-564. 
Table 1: Trade Ratio to Expenditure Ratio

\begin{tabular}{ccccccc}
\hline \hline & $(1)$ & $(2)$ & $(3)$ & $(4)$ & $(5)$ & $(6)$ \\
\hline$\Delta$ tot & $-0.176^{* *}$ & & $-0.143^{*}$ & & $-0.169^{* *}$ & $-0.136^{*}$ \\
tot & & $-0.529^{* * *}$ & & $-0.523^{* * *}$ & & \\
tbdd $_{t-1}$ & & & $-0.066^{* * *}$ & & & $-0.065^{* * *}$ \\
tot $_{t-1}$ & & & $-0.109^{* * *}$ & & & $-0.110^{* * *}$ \\
& & & & & & \\
NIIY & & & & -1.612 & & \\
$\Delta$ NIIY & & & & & $-1.274^{*}$ & $-1.276^{* *}$ \\
LR Price & & & 1.65 & & & 1.70 \\
N & 138 & 139 & 138 & 139 & 138 & 138 \\
& 0.047 & 0.259 & 0.281 & 0.257 & 0.083 & 0.319 \\
\hline \hline
\end{tabular}

1980q1 to 2014q3. NIIY denots the ratio net inventory investment to GDP.

${ }^{*} 10$ percent,${ }^{* *} 5$ percent, ${ }^{* * *} 1$ percent.

Table 2: Contribution of business cycle to trade balance

\begin{tabular}{lccc}
\hline \hline & Diff & Levels & SR/LR \\
\hline Trade-expenditure ratio & 21.2 & 25.9 & 59.6 \\
Trade ratio & 26.7 & 31.1 & 62.5 \\
\hline \hline
\end{tabular}


Table 3: Avg. Trade balance to gdp since 1991

\begin{tabular}{lcc}
\hline \hline & Levels & Contribution \\
\hline Data & -2.95 & $100 \%$ \\
Counter factual* & -1.58 & $53.5 \%$ \\
Trade contribution Global & -1.37 & $46.5 \%$ \\
\hline \hline
\end{tabular}

*Based on (1986 trade share)

Table 4: Decomposition of trade balance to gdp since 1991

\begin{tabular}{lccc}
\hline \hline & Diff & Levels & SR/LR \\
\hline Business Cycle & 14.3 & 16.7 & 33.4 \\
Rel. Prices & 11.3 & 13.9 & 31.9 \\
Expenditures & 3.0 & 2.8 & 1.5 \\
& & & \\
Trade Integration & 85.7 & 83.3 & 66.6 \\
Uneven & 39.2 & 36.8 & 20.1 \\
Global & 46.5 & 46.5 & 46.5 \\
\hline \hline
\end{tabular}


Table 5: Parameters

\begin{tabular}{llcc}
\hline \hline$\beta$ & $\sigma$ & $\zeta_{b}$ & $\psi$ \\
0.99 & 2 & 0.001 & 0.005 \\
& & & \\
Parameter & Value & Target & \\
\hline$\gamma$ & 0.30 & $\mathrm{~L}=1 / 4$ & \\
$a_{1}$ & 0.1551 & $10 \%$ trade share & \\
$f_{0}$ & 0.1278 & $20 \%$ export & \\
$f_{1}$ & 0.0373 & $2.5 \%$ exit rate from exporting & \\
$\sigma_{\eta}$ & 0.15 & $50 \%$ exporter premium & \\
$\theta$ & 4 & $33 \%$ Markup & \\
$\zeta$ & 0.5 & $50 \%$ pass-through & \\
$\rho$ & 1.65 & Armington Elasticity & \\
\hline \hline
\end{tabular}

Table 6: Decomposition of trade ratio

\begin{tabular}{ccccc}
\hline \hline & Data & \multicolumn{2}{c}{ No Externality } \\
& & Benchmark & PTM & No PTM \\
Variance*100 & 240 & 89.1 & 34.5 & 11.6 \\
Share* $^{*}$ & 100 & 27.4 & 12.6 & 5.1 \\
Since 1991 & \multicolumn{3}{c}{5.6} \\
Share* & 100 & 30.5 & 13.2 & 5.6 \\
\hline \hline * Allocates covariance in proportion to variance \\
\hline \hline
\end{tabular}


Figure 1: US Real Trade balance \& Trade share of GDP

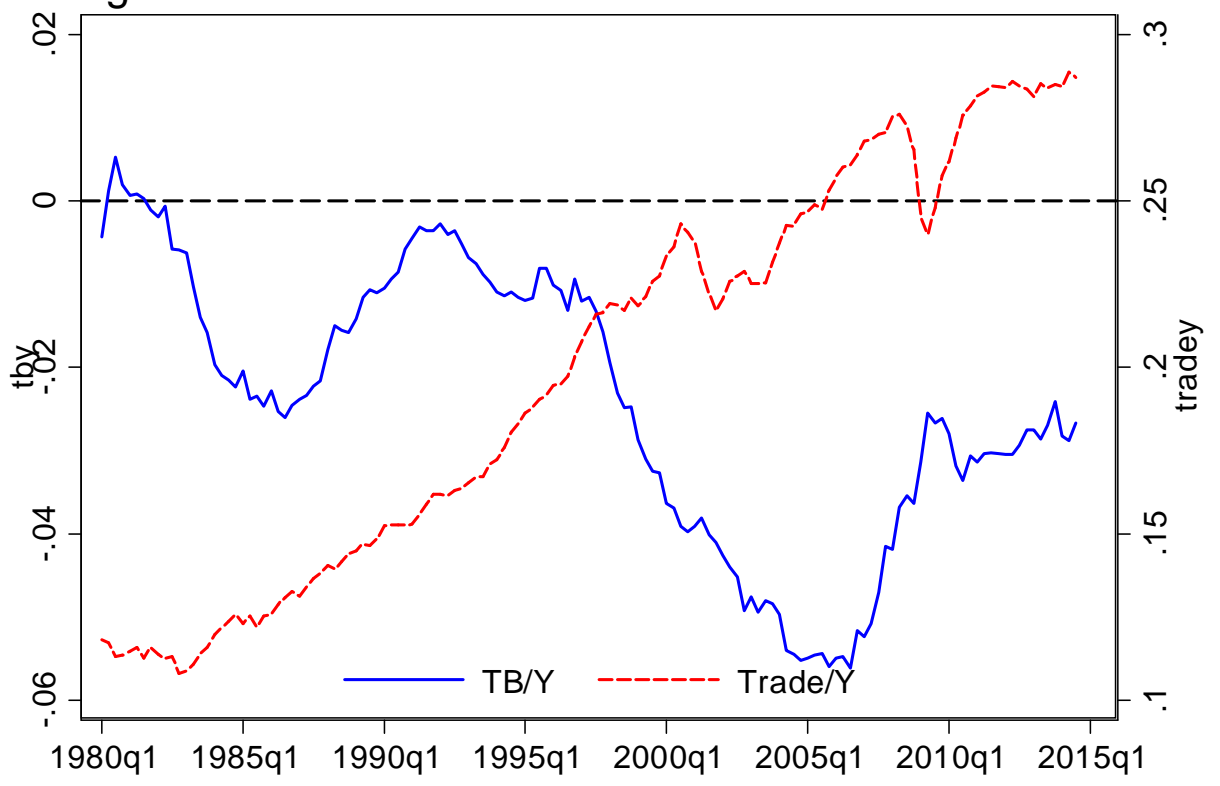

Figure 2: Contribution of Trade Growth to US Real Net Exports

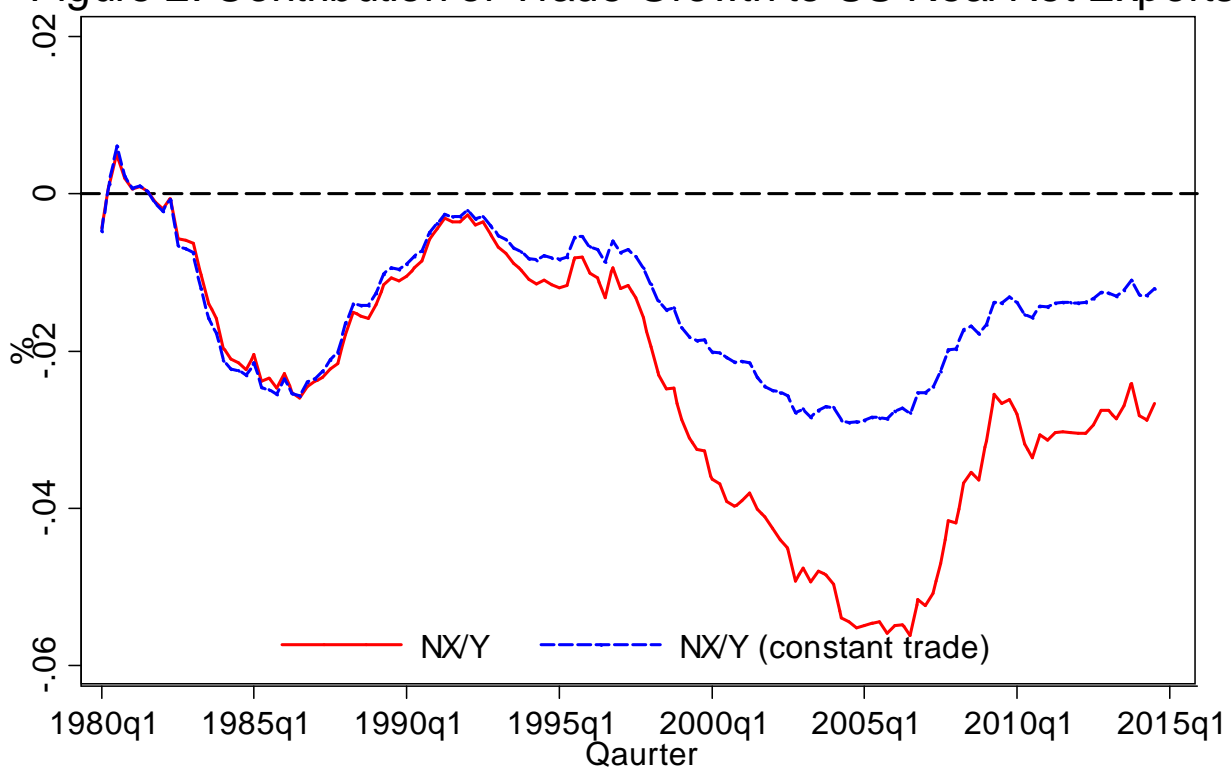

Note: Trade to GDP based on 1986 avg 
Figure 3: US Trade Ratio Data and Empirical Models

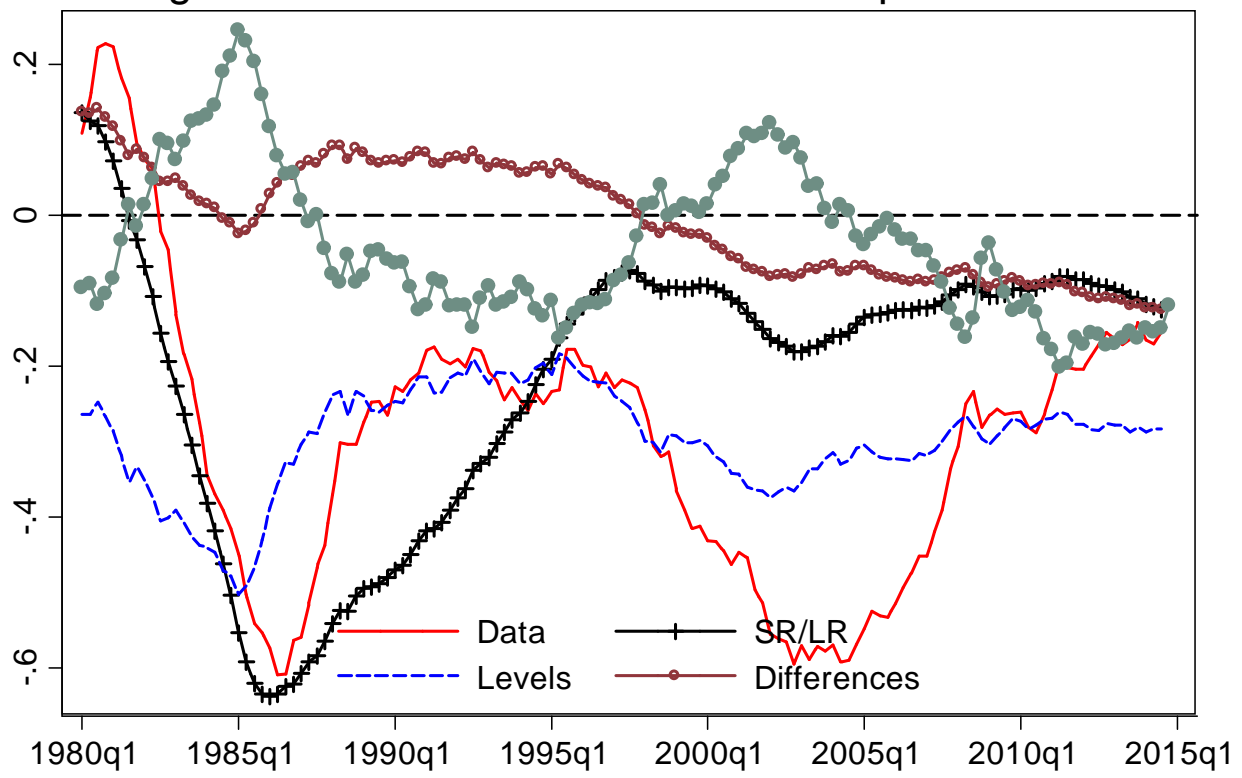

Figure 4: Wedge Gap and Trade Ratio

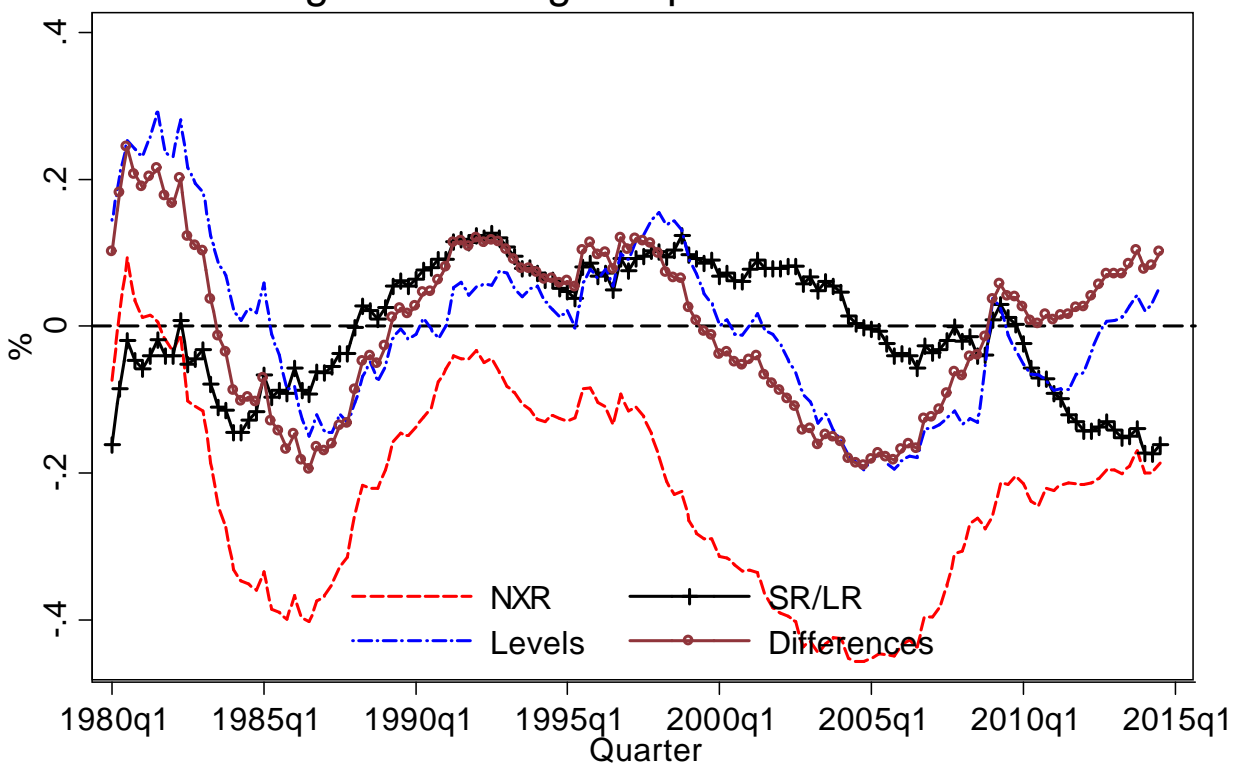

Note: Based on US from 1980q1 to 2014q4 
Figure 5: Home and Foreign Wedge

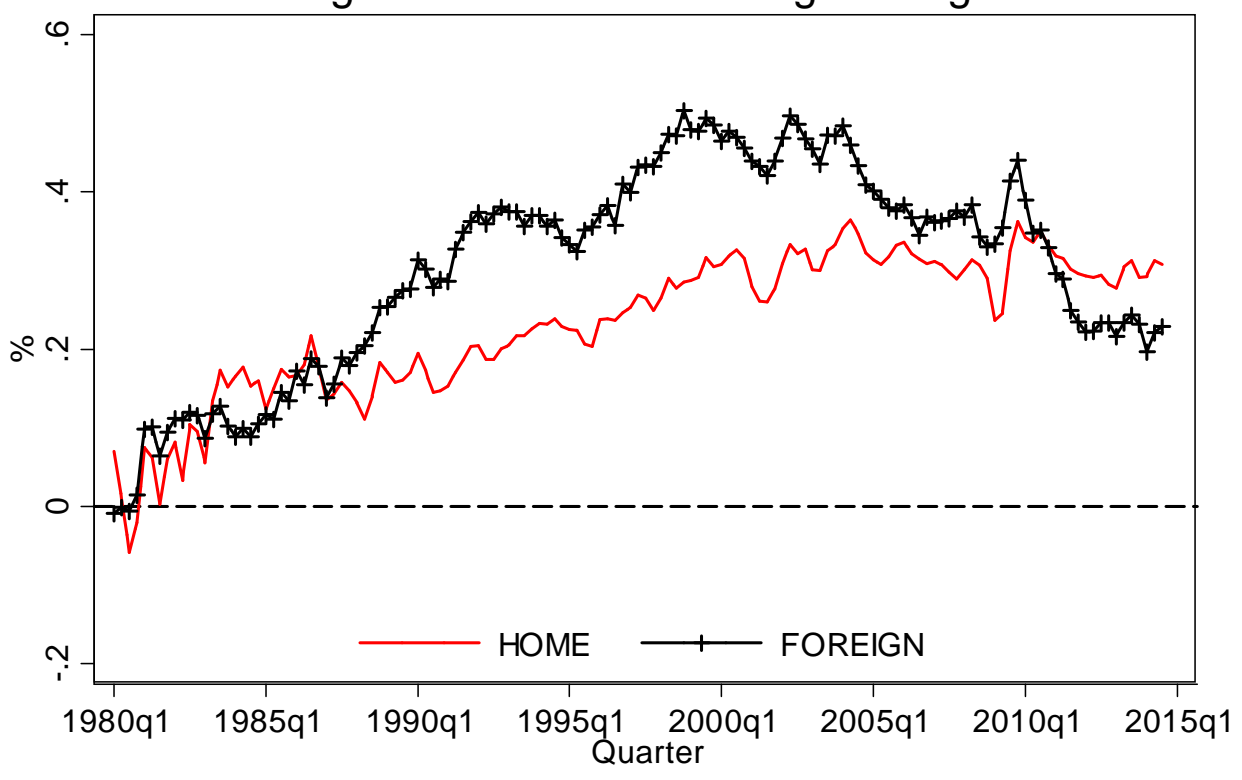

Note: Based on US from 1980q1 to 2014q4 
Figure 6: Trade Ratio and Trade Wedge.
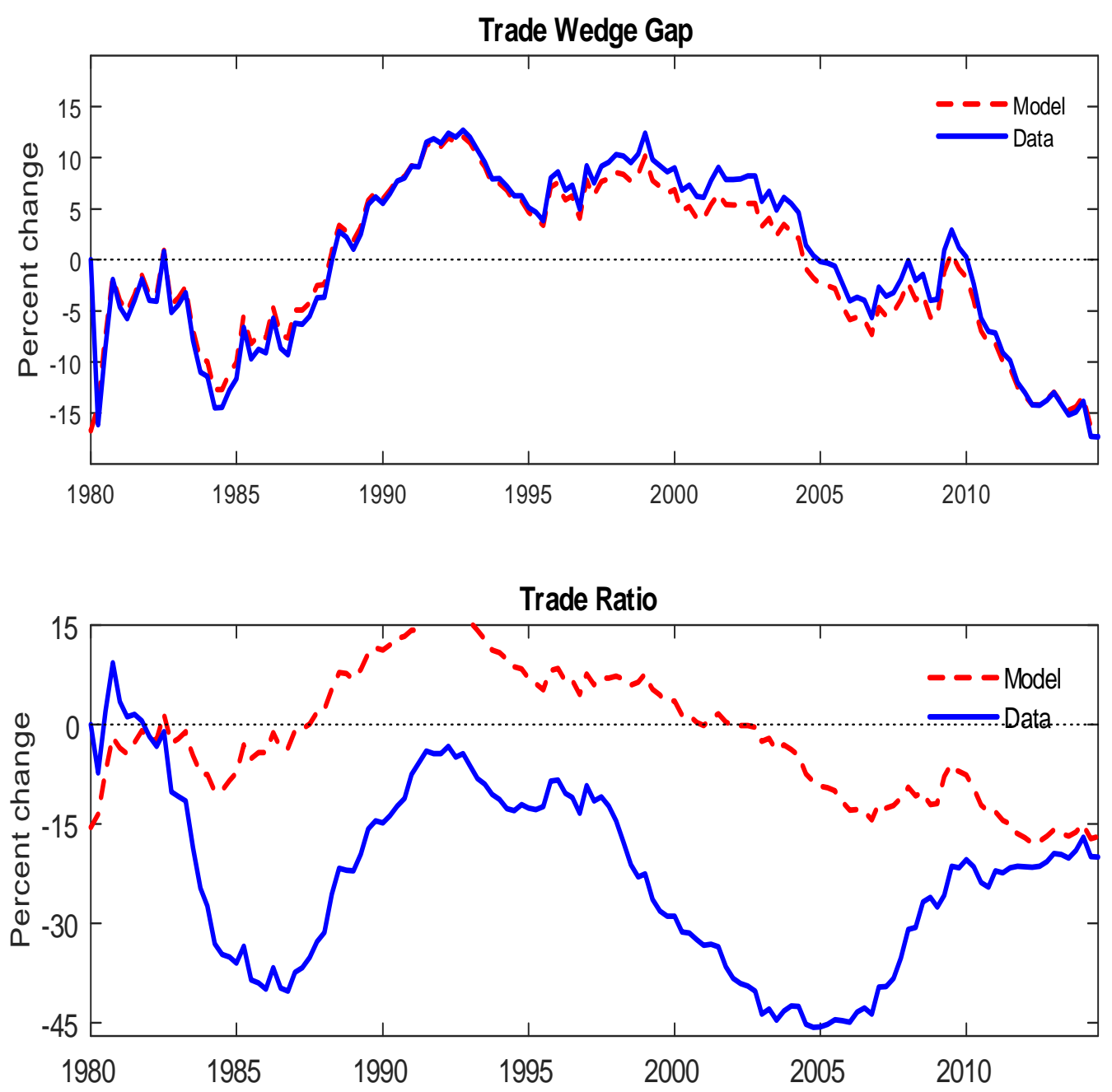
Figure 7: Trade Ratio Fluctuations with and without pricing-to-market.

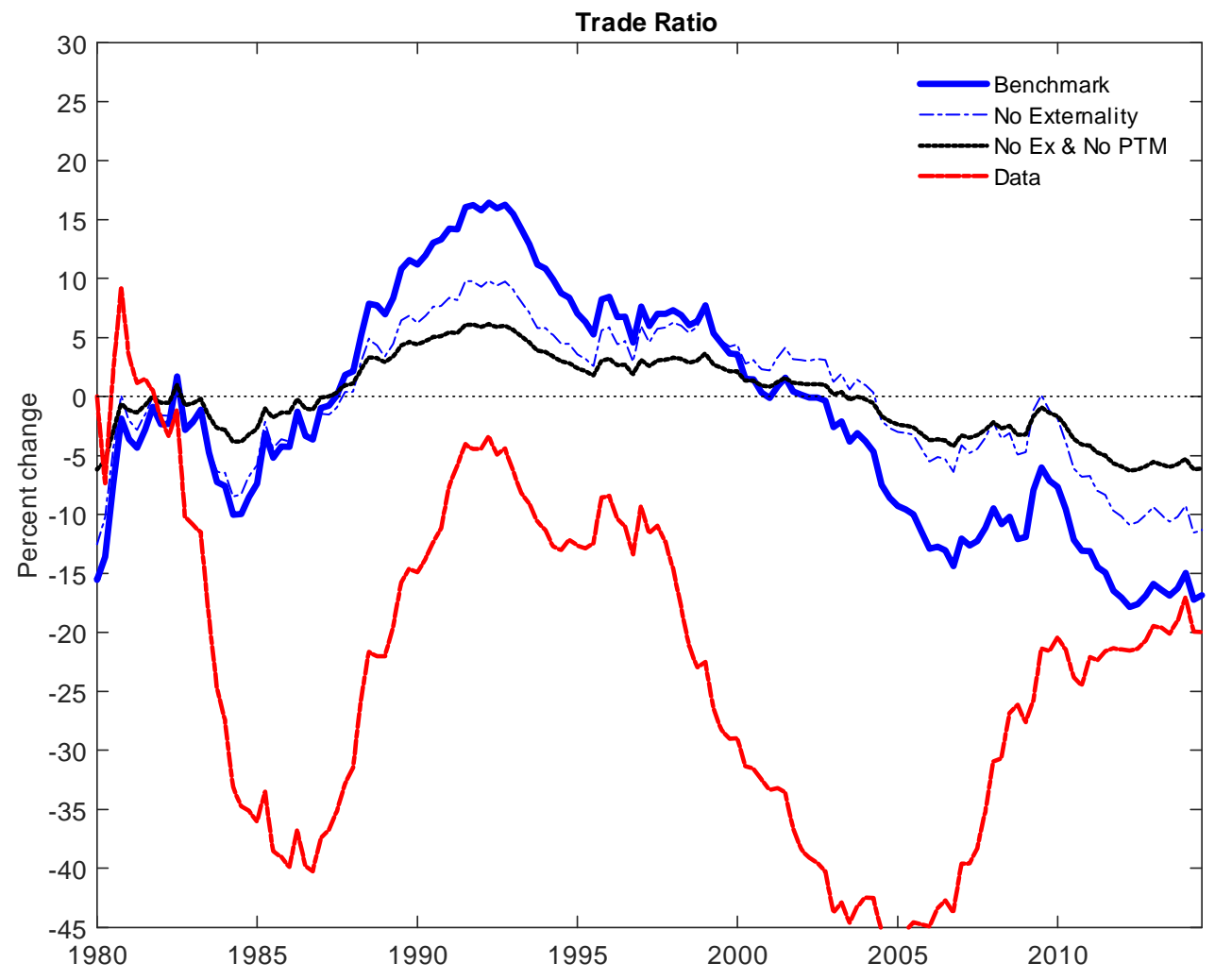


Figure 8: Persistent trade shock (0.95)
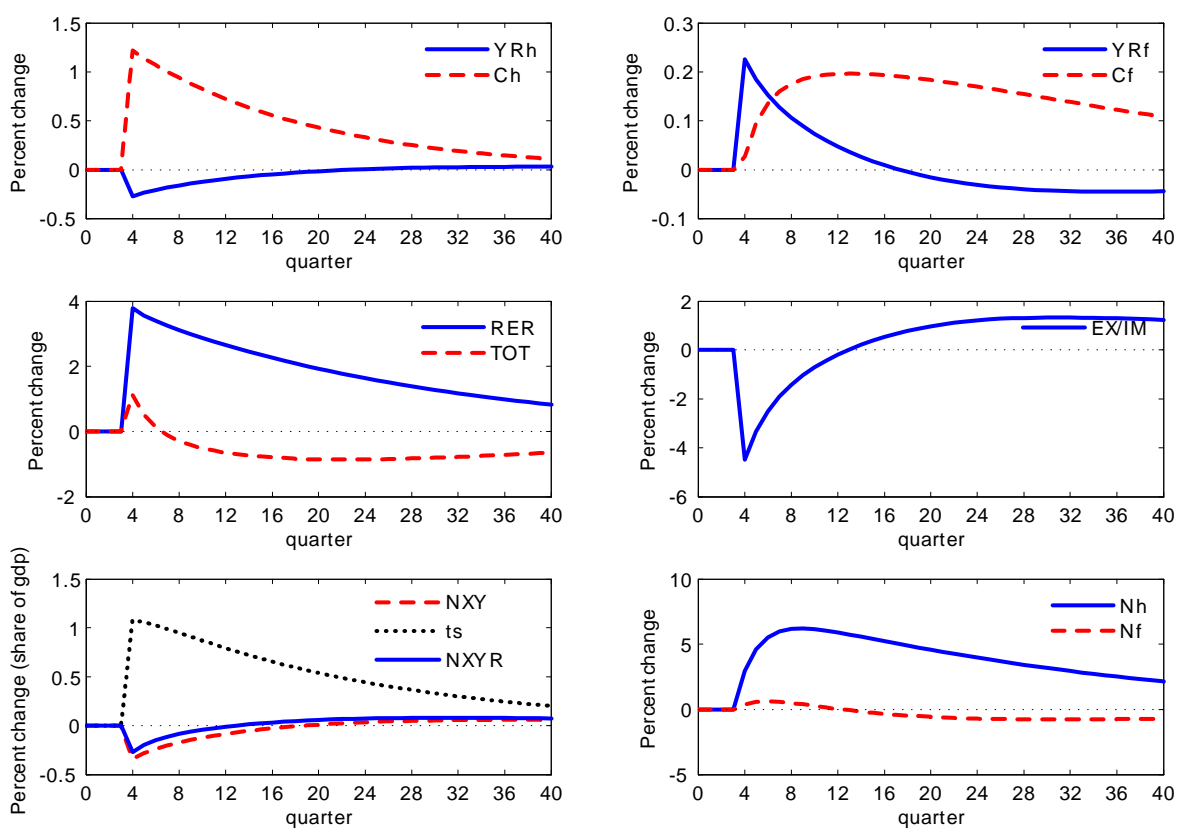

Figure 9: Persistent trade shock (0.75)
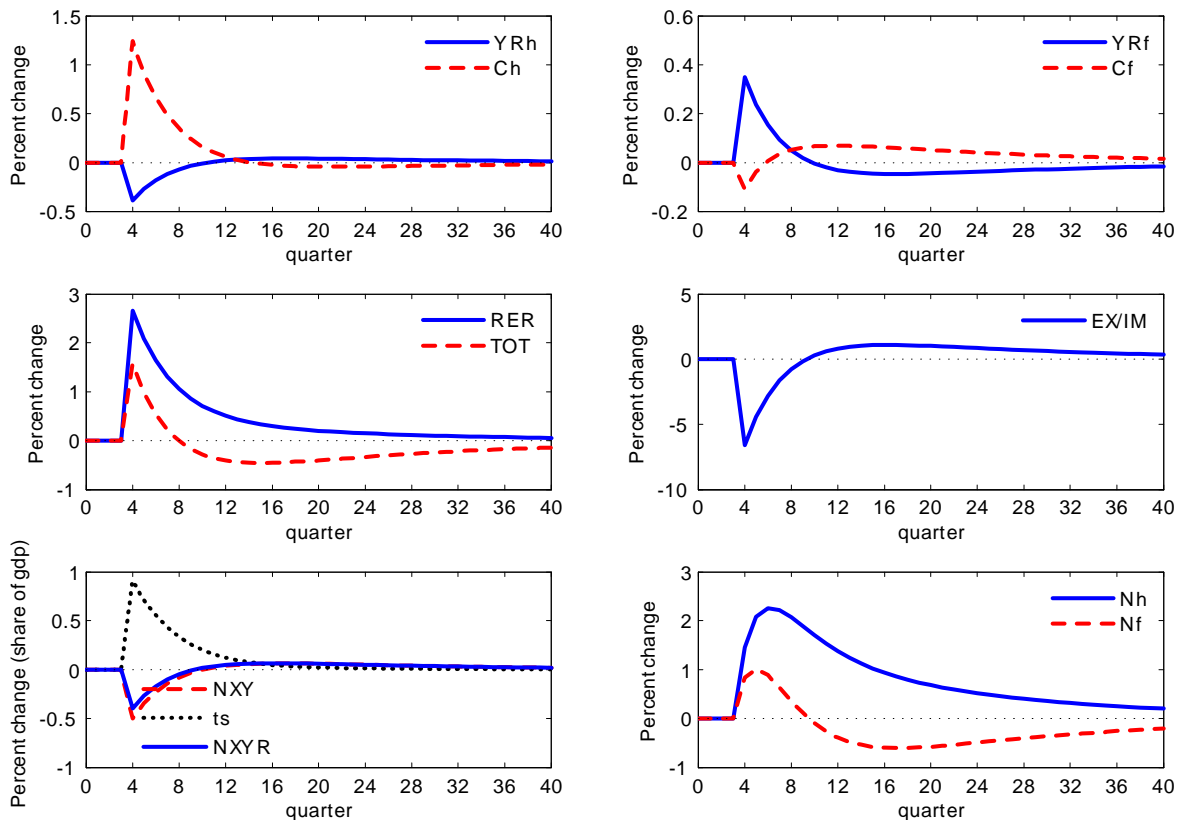
Figure 10: Persistent trade shock (0.95) and High Armington elasticity $(\rho=3.3)$
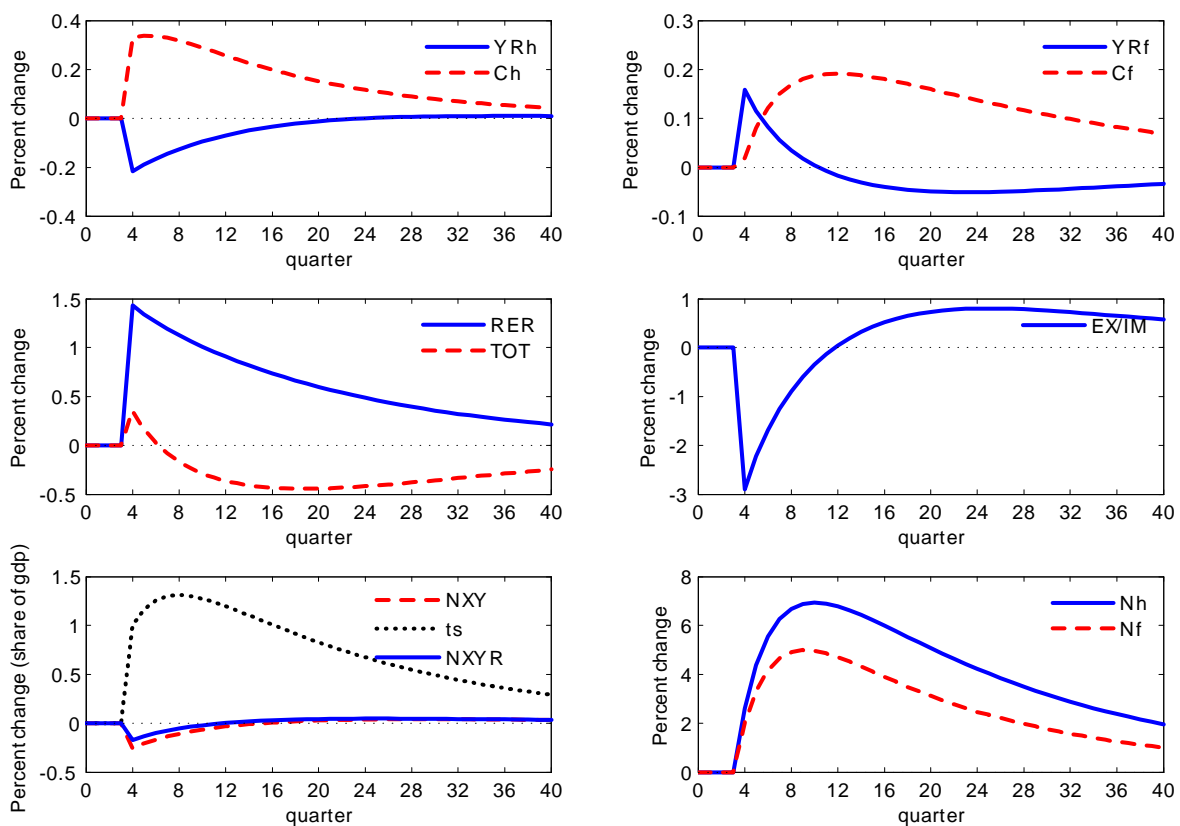

Figure 11: Persistent trade shock (0.95) and Low Armington elasticity $(\rho=0.55)$
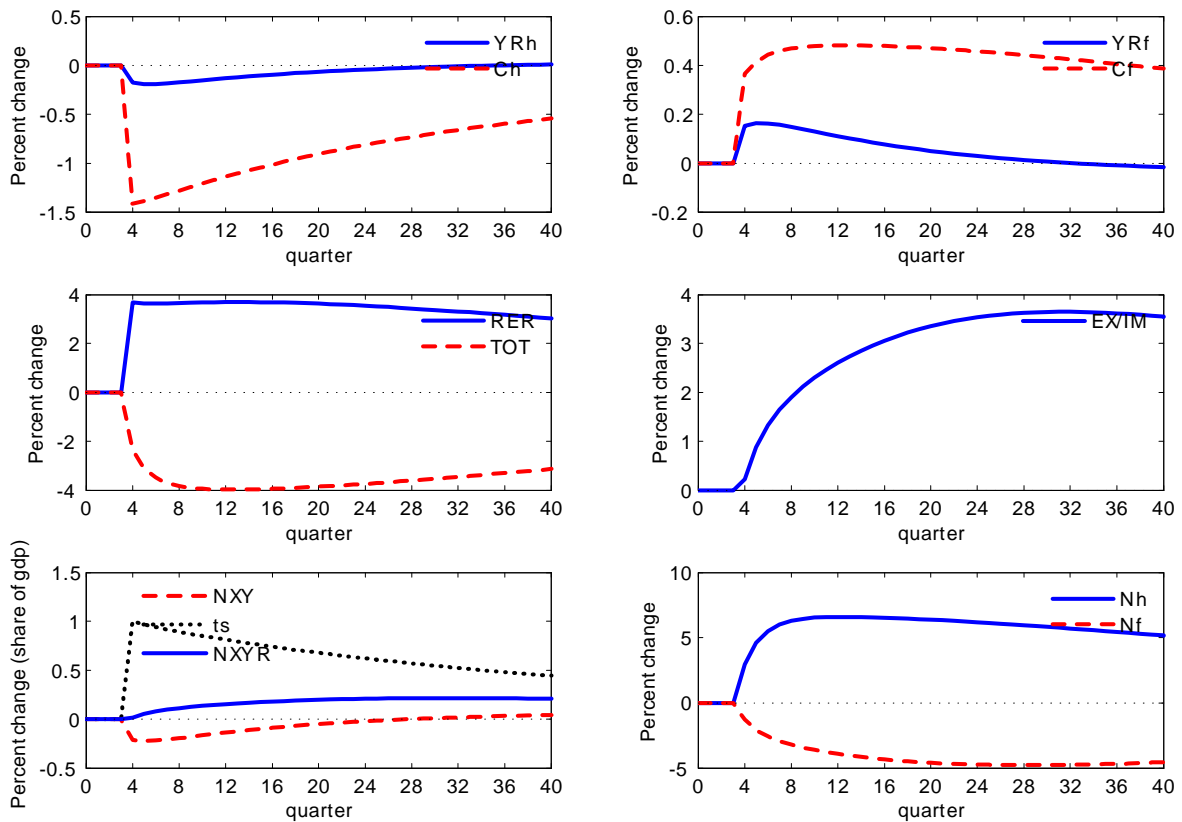